\title{
Influence of Bacterial Carbonate Precipitation on the Compressive Strength and Water Absorption of Fly Ash Concrete
}

\author{
Peihao Li ${ }^{1, \text { a }}$, Chongqi Liu ${ }^{1, b}$, Wei Zhou ${ }^{2, c}$ \\ ${ }^{1}$ College of Civil Engineering and Architecture, Zhejiang University of Technology, Hangzhou, China \\ ${ }^{2}$ School of Aerospace Engineering and Applied Mechanics, Tongji University, Shanghai, China

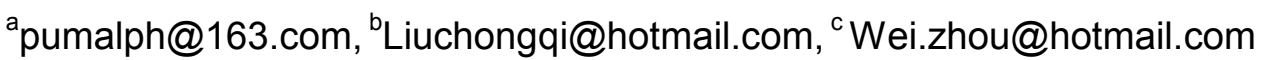

\begin{abstract}
Keywords: Bacteria, Concrete, Fly ash, Compressive strength, Durability, Water absorption
Abstract. The aim of this study was to investigate the influence of bacterial carbonate precipitation on the compressive strength and capillary water uptake of fly ash concrete. Cement was replaced with three percentages $(10 \%, 20 \%$ and $30 \%)$ with fly ash by weight. The effects of bacterial induced precipitation on concrete strength were studied through compressive strength test. Tests were carried out for compressive strength and water absorption at the age of 28 days. Experimental results indicated that Acinetobacterjohnsonii induced carbonate precipitation in fly ash concrete enhanced the compressive strength. Bacterial carbonate precipitation effectively reduces capillary water uptake, and reduced the porosity of fly ash concrete. Acinetobacterjohnsonii induced carbonate precipitation improves strength and durability of fly ash concrete.
\end{abstract}

\section{Introduction}

Concrete is the most widely used man made building material all over the world, and comprised of aggregate and cement. Fly ash acts as a partial replacement material for both Portland cement and fine aggregate. Fly ash can be used as a partial component of concrete because of its lightweight and high thermal insulation. Use of fly ash-a recovered resource reduces depletion of natural resources and also reduces the energy-intensive manufacturing of other concrete ingredients, leading to savings in both energy usage and emissions of greenhouse gases [1-2]. The porosity of concrete material along with ingress of detrimental components in moist environments, such as acids, chlorides, sulfates and so on, seriously reduce concrete material strength and concrete structure service life. Some measures were taken to diminish the uptake of water or to slow down or even to eliminate concrete degradation. Bacterial carbonate precipitation plays an important role in limiting the infiltration of detrimental components into concrete and lead to the exploration of technique in the field of concrete materials [3-4]. Various microorganisms have been used to increase the compressive strength of cement mortar and durability of concrete structures [5]. The most promising and feasible application is believed to enhance durability of concrete structures [6-7]. Bacterial calcite deposition observed nearly eight times reduction in chloride permeability, and so the life of the concrete structures can be increased [8]. The aim of this study was to investigate the influence of strain Acinetobacterjohnsonii induced carbonate precipitation on the compressive strength and capillary water uptake of fly ash concrete. Cement was replaced with three percentages $(10 \%, 20 \%$ and $30 \%)$ with fly ash by weight. The effects of bacterial induced precipitation on concrete strength were studied through compressive strength test. Water absorption of concrete were analyzed by water absorptivity test.Tests were carried out for compressive strength and water absorption at the age of 28 days. Durability was assessed from the permeation properties and resistance towards degradation processes.

\section{Materials and methods}

Bacterial strain and culture media. The microorganism used throughout the study was Acinetobacterjohnsonii (The strain was isolated and purified from karst soil, and then through physiological and biochemical characteristics and based on the 16s rRNA sequence and the phylogenetic analysis, it was identified as Acinetobacterjohnsonii.). For inoculum preparation, 
Acinetobacterjohnsonii was precultured in liquid medium $\mathrm{B} 4\left(\mathrm{Ca}\left(\mathrm{CH}_{3} \mathrm{COO}\right)_{2} 2.5 \mathrm{~g}\right.$; Yeast extract, $4.0 \mathrm{~g}$; Glucose 10.0g; agar 15.0g; $\mathrm{pH} \mathrm{8.0;} \mathrm{and} \mathrm{distilled} \mathrm{water,} 1$ L.). Individual ingredients were autoclaved separately and mixed afterward to avoid precipitation. Precipitation experiments were carried out in liquid medium (BT) containing the following $\mathrm{L}^{-1}$ of glass distilled water: $\mathrm{Ca}\left(\mathrm{CH}_{3} \mathrm{COO}\right)_{2}, 2.5 \mathrm{~g}$; Broth $3 \mathrm{~g}$; Yeast extract, $0.5 \mathrm{~g} ; 0.05 \mathrm{M}$ Tris buffer; distilled water, $1 \mathrm{~L} ; \mathrm{pH} 9.0$. The $\mathrm{pH}$ of the medium was adjusted to 9.0 with $\mathrm{NaOH}$ prior to autoclaving for $20 \mathrm{~min}$ at $121^{\circ} \mathrm{C}$.

Fly ash concrete specimens and bio-deposition experiments. Concrete specimens were made by using ordinary Portland cement. The composition of the concrete mix: cement, $442 \mathrm{Kg}$; sand, $473 \mathrm{Kg}$; aggregates, $1280 \mathrm{Kg}$; and water, $221 \mathrm{Kg}$. Fly ash has a very high content of amorphous silicon dioxideand consists of fine spherical particles along with small amounts of iron, magnesium, and alkali oxides were found.The replacement percentage of fly ash was by weight of cement. The percentage use of fly ash was $0 \%, 10 \%, 20 \%$ and $30 \%$. Chemical properties of fly ash:SiO2 $51.4 \%$, $\mathrm{A} 12 \mathrm{O} 332.64 \%, \mathrm{Fe} 2 \mathrm{O} 35.85 \%, \mathrm{MgO} 2.31 \%, \mathrm{CaO} 3.72 \%$, SO3 0.57\%.Moulds with dimensions of $70 \mathrm{~mm} \times 70 \mathrm{~mm} \times 70 \mathrm{~mm}$ were used. After casting, all moulds were placed in an air-conditioned room with a temperature of $20 \pm 2^{\circ} \mathrm{C}$ and a relative humidity of more than $90 \%$ for a period of $24 \mathrm{~h}$. After demoulding, the specimens were cured for more than 28 days. Some specimens with dimensions of $70 \mathrm{~mm} \times 70 \mathrm{~mm} \times 70 \mathrm{~mm}$ were used for compressive strength test, others with dimensions of $40 \mathrm{~mm} \times 40 \mathrm{~mm} \times 160 \mathrm{~mm}$ were used for capillary water absorption and accelerated carbonation test.

Bacterial carbonate precipitation experiments were conducted in liquid media. The culture was incubated on a shaker with constant shaking $160 \mathrm{rpm}$ for $24 \mathrm{~h}$ at $30^{\circ} \mathrm{C}$, which is the optimal duration for Acinetobacterjohnsonii to reach a density of $2.17 \times 10^{7} \mathrm{cfu} / \mathrm{mL}$ during the exponential growth. Cell concentrations were determined by viable cell counting on B4 plates. Specimens were placed in BT culture media and inoculated with Acinetobacterjohnsonii. A minimum of three specimens were run in each experiment.

Bacterial carbonate precipitation concrete specimens were immersed for $24 \mathrm{~h}(10 \pm 5 \mathrm{~mm}$ depth$)$ in a precultured $24 \mathrm{~h}$ old stock culture of Acinetobacterjohnsonii. After this inoculation, specimens were wiped with a paper towel to remove excess liquid. Following this wiping, specimens were immersed ( $10 \pm 5 \mathrm{~mm}$ depth) in precipitation medium. The specimens were removed from the medium in 3 days, 7days and 28 days, and left to dry for a week at room temperature. Control experiments identical to those indicated above were carried out without bacterial inoculation. The same procedure was used to check contamination of inoculated specimens.

Compressive strength test of concrete specimens, Acinetobacterjohnsonii was grown in B4 media. Fly ash was added by replacing the amount of cement at the concentrations of $10 \%, 20 \%$ and $30 \%$. A cube mould of $70 \mathrm{~mm}$ was used,sand and cement were thoroughly mixed, adding along with grown culture of Acinetobacterjohnsonii correspondence to $4 \times 10^{7} \mathrm{cfu} / \mathrm{ml}$. Cubes were cast and compacted in a vibration machine. After de-molding, all specimens were cured in BT medium at room temperature until compression testing at the intervals of 3, 7 and 28 days. The concrete cubes were cured for 3, 7 and 28 days and tested for compressive strength. Control experiments were also prepared in a same way without adding bacterial cells.

Water absorption test. Absorptivity test was carried out to determine the increase in resistance towards water penetration. Concrete specimens were primarily coated at 4 sides adjacent to biodepostion treated side with polysiloxane and silicon paint. After coating, specimens were dried in an oven set at $105^{\circ} \mathrm{C}$ until a constant weight was reached.

The preconditioned specimens were exposed to $10 \pm 1 \mathrm{~mm}$ of water in an atmosphere of $20 \pm 2{ }^{\circ} \mathrm{C}$ and R.H. of $60 \pm 10 \%$, with the treated side facing downwards and water level about $2 \mathrm{~mm}$ above the base of the specimen. The water level was kept constant through addition of tap water. The sorptivity coefficient, $\mathrm{k}\left[\mathrm{cm} \mathrm{s}^{-1 / 2}\right]$, was obtained by using the following expression: $\frac{Q}{A}=K \sqrt{t}$ 
Where $\mathrm{Q}$ is the amount of water absorbed $\left[\mathrm{cm}^{3}\right]$; $\mathrm{A}$ is the cross section of the specimen that was in contact with water $\left[\mathrm{cm}^{2}\right]$; $\mathrm{t}$ is the time $[\mathrm{s}], \mathrm{Q} / \mathrm{A}$ was plotted against the square root of time, then $\mathrm{k}$ was calculated from the slope of the linear relation between the former.

\section{Results and discussion}

Compressive strength test. Fly ash concrete cubes were cured for 3, 7 and 28 days and tested for compressive strength. Compressive strengths of concrete cubes were tested to determine the efficiency of improvement by Acinetobacterjohnsonii induced precipitation. Fig. 2 shows the 3, 7 and 28 day compressive strength of fly ash concrete cubes containing Acinetobacterjohnsonii cells. The compressive strength had significantly increased for the concrete cubes that contained microbial cells. Concrete cubes containing bacterial cells showed about $21.1 \%$ improvement in compressive strength at 28 days compare to control specimen without bacteria. For fly ash concretes specimens, there was $19.7 \%$ improvement in compressive strength of concrete specimens with $10 \%$ fly ash content. Similarly, there was $16.0 \%$ and $8.7 \%$ improvement in compressive strengths of specimens with $20 \%$ and $30 \%$ fly ash.

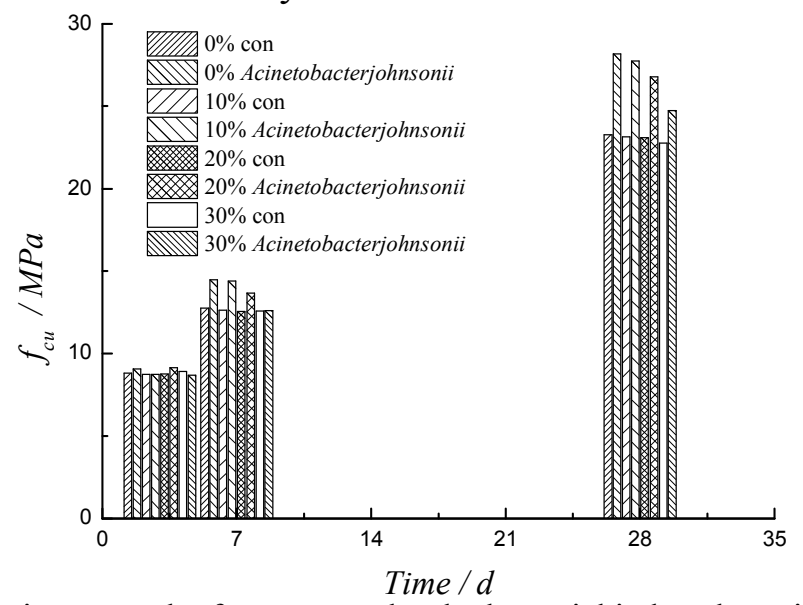

Fig.1. Compressive strength of concrete cubes by bacterial induced precipitation.

Water absorption analysis. Fig. 2 shows the effects of bacterial induced carbonate precipitation on the water absorption for fly ash concrete specimens with different replacement percentage of fly ash. Fly ash concrete specimens by biotreatment show significantly less water absorption compared to untreated specimens. The $30 \%$ fly ash specimens by biotreatment show a higher absorption than $20 \%$ and $10 \%$ fly ash specimens. Water absorption capacity of $30 \%$ fly ash concretes specimens decreased by $48.8 \%$. Water absorption of specimens increased with the increase in replacement percentage of fly ash. The presence of bacteria and Acinetobacterjohnsonii induced precipitation resulted in a significant decrease in the water uptake compared to control specimens. The deposition of a layer of calcium carbonate on the surface and inside pores of the concrete specimens resulted in a decrease of water absorption.

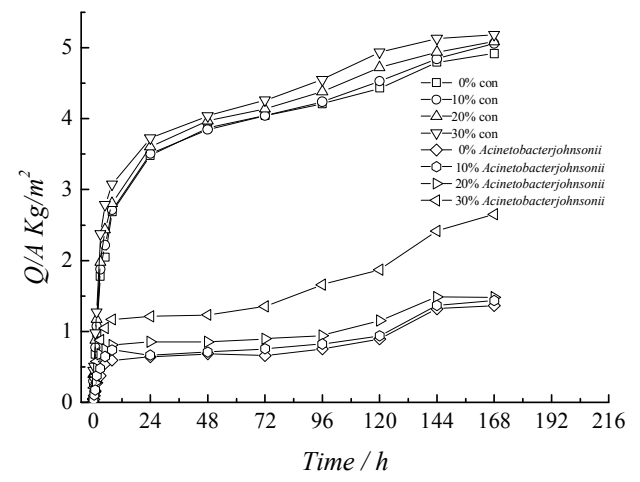

Fig.2. The influence of bacterial induced carbonate precipitation on surface of concrete samples on the rate of water absorption. 


\section{Conclusions}

1. Compressive strengths of fly ash concrete cubes were tested to determine the efficiency of improvement by Acinetobacterjohnsonii induced precipitation. Compressive strength of concrete specimens with $10 \%$ fly ash content increased by $19.7 \%$. Similarly, compressive strengths of specimens with $20 \%$ and $30 \%$ fly ash increase by $16.0 \%$ and $8.7 \%$, respectively.

2. Water absorption of specimens increased with the increase in replacement percentage of fly ash. The presence of Acinetobacterjohnsonii induced precipitation resulted in a significant decrease in the water uptake compared to control specimens. The deposition of a layer of calcium carbonate on the surface and inside pores of the concrete specimens resulted in a decrease of water absorption.

\section{Acknowledgements}

This work was financially supported by Natural Science Foundation of China (No.51008281), the China postdoctoral science Foundation (No.2012M510119) and National Basic Research Program of China (No.2009CB623200).

\section{References}

[1] V.Achala, X. Pan, N.r Ozyurt.Ecol. Eng. Vol. 37 (2011),p. 554-559.

[2] W. De Muynck, K.Cox, N. De Belie:Cem. Concr. Res. Vol. 38 (2008), p.1005-1014.

[3] H.K. Kim, S.J. Park, J.I. Han,et al.Constr. Build. Mater. Vol. 38 (2013),p.1073-1082.

[4] R. Pei, J. Liu, S. Wang,et al:Cem.Concr. Comp. Vol. 39 (2013), p. 122-130.

[5] V. Achal1,A. Mukherjee, M. S. Reddy:J. Mater. Civ. Eng. Vol. 23 (2011), p.730-734.

[6] Kunal, R.Siddique, A. Rajor:Constr. Build. Mat. Vol. 52 (2014), p. 42-51.

[7] R. Pei, J.Liu, S. Wang. Cem.Concr.Comp.Vol.55 (2015), p.186-195.

[8] N. Chahal, R. Siddique, A. Rajor:Constr. Build.Mater. Vol. 28 (2012), p. 351-356. 